\title{
HUBUNGAN ANTARA KOMUNIKASI INTERPERSONAL DENGAN ORGANIZATIONAL CITIZENSHIP BEHAVIOR PADA KARYAWAN DEPARTEMEN SUMBER DAYA MANUSIA PT. SEMEN PADANG
}

\author{
Herio Rizki Dewinda' Hidayatul Annisa \\ Universitas Putra Indonesia "YPTK" Padang \\ email: hrdewinda@ upiyptk.ac.id, hidayatulannisa1@gmail.com,
}

\begin{abstract}
This study aims to determine the relationship between interpersonal communication and organizational citizenship behavior in employees of the human resources department of PT. Semen Padang. The independent variable in this study is interpersonal communication and the dependent variable is organizational citizenship behavior. The measuring instrument used in this study is the scale of interpersonal communication and the scale of organizational citizenship behavior. The sampling technique in this study used a saturated sample technique. The sample in this study were 75 employees of the human resources department of PT Semen Padang. Validity and reliability test in this study usingtechnique Alpha Cronbach. The results of the validity coefficient on the scale of interpersonal communication ranged from $\mathrm{r}_{\mathrm{ix}}=0.323$ to $\mathrm{r}_{\mathrm{ix}}=0.680$ and reliability of $\alpha=0.939$ while on the OCB scale the value of the different power index values ranged from $\mathrm{r}_{\mathrm{ix}}=0.336$ to $\mathrm{r}_{\mathrm{ix}}=0.833$ with reliability coefficients amounting to $\alpha=0.947$. Based on data analysis, the correlation value of $r=0.455$ is obtained with a significance level of 0.000 , which means that the hypothesis is accepted. This shows that there is a significant relationship between interpersonal communication and organizational citizenship behavior in the human resources department of PT Semen Padang employees.
\end{abstract}

Keywords: interpersonal communication,organizational citizenship behavior, employees

\begin{abstract}
Abstrak
Penelitian ini bertujuan untuk mengetahui hubungan antara komunikasi interpersonal dan organizational citizenship behavior pada karyawan departemen sumber daya manusia PT.Semen Padang. Variabel bebas dalam penelitian ini adalah komunikasi interpersonal dan variabel terikat adalah organizational citizenship behavior. Alat ukur yang digunakan dalam penelitian ini adalah skala komunikasi interpersonal dan skala organizational citizenship behavior. Teknik pengambilan sampel dalam penelitian ini menggunakan teknik sampel jenuh. Sampel dalam penelitian ini adalah 75 orang karyawan departemen sumber daya manusia PT.Semen Padang. Uji validitas dan reliabilitas pada penelitian ini menggunakan teknik Alpha Cronbach. Hasil koefisien validitas pada skala komunikasi interpersonal berkisar dari $\mathrm{r}_{\mathrm{ix}}=0,323$ sampai dengan $\mathrm{r}_{\mathrm{ix}}=0,680$ dan reliabilitas sebesar $\alpha=0,939$ sedangkan pada skala OCB diperoleh nilai indeks daya beda aitem berkisar dari $r_{i x}=0,336$ sampai dengan $r_{i x}=0,833$ dengankoefisien reliabilitas sebesar $\alpha=0,947$.Berdasarkan analisis data, diperolehnilai korelasi sebesar $r=0,455$ dengan taraf signifikansi 0,000 yang berarti hipotesis diterima. Hal ini menunjukkan bahwa ada hubungan yang signifikan antara komunikasi interpersonal dan organizational citizenship behavior pada karyawan departemen sumber daya manusia PT.Semen Padang.
\end{abstract}

Kata kunci: komunikasi interpersonal,organizational citizenship behavior, karyawan 


\section{Pendahuluan}

Pada era globalisasi ini semakin banyak masyarakat yang berlomba-lomba ingin menjadi pegawai dengan berbagai alasan. Namun, perkembangan dunia industri dan organisasi yang semakin maju saat ini menuntut adanya persaingan yang ketat diantara perusahaan yang berdampak pada selektifnya perusahaan menyaring pencari kerja yang akan melamar di perusahaannya. Tindakan ini bukan tanpa alasan, karena sejatinya perusahaan tentu menginginkan sumber daya manusia yang sesuai dengan visi dan misi perusahaan. Salah satunya adalah sumber daya manusia yang dapat memberi lebih kepada perusahaan.

Amanda (2014) mengatakan bahwa organisasi yang efektif membutuhkan karyawan yang tidak hanya menjalankan peranan tertentu saja, namun juga membutuhkan karyawan yang mau menjalankan tingkah laku yang berada di luar kewajiban formalnya atau melakukan perilaku extra role. Perilaku ini didalam konteks psikologi industri dan organisasi dikenal dengan istilah organizational citizenship behavior. Hardaningtyas (dalam Setyawanti, 2012) mengungkapkan bahwa OCB lebih berhubungan dengan bagaimana karyawan bertindak sebagai makhluk sosial. OCB merupakan wujud kegiatan sukarela dari anggota organisasi yang turut mendukung fungsi organisasi sehingga perilaku ini lebih bersifat altruistik yang di ekspresikan dengan bentuk tindakan nyata yang memperlihatkan sikap tidak mementingkan diri sendiri dan memperhatikan kesejahteraan orang lain. Untuk melakukan hal-hal baik, seseorang memanglah tidak selalu dikendalikan oleh sesuatu yang menguntungkan dirinya. Dengan kemampuan komunikasi yang baik dan berempati, karyawan dapat mengerti orang lain beserta lingkungannya serta bisa menyeimbangkan nilai-nilai individual yang dianutnya dengan nilai-nilai yang di percayai oleh lingkungannya, sehingga munculah perilaku sebagai good citizen.

Banyak faktor-faktor yang mempengaruhi seorang karyawan sehingga karyawan bersedia menampilkan perilaku seperti OCB untuk menjadi good citizen. George dan Brief (dalam Novianto, 2009) berpendapat kualitas interaksi antara sesama karyawan dan iklim kelompok kerja yang positif akan mempengaruhi suasana hati seseorang dalam mengambil keputusan untuk melakukan tindakan membantu orang lain. Interaksi yang baik diantara anggota organisasi akan dapat membentuk pola komunikasi yang asosiatif. Interaksi yang berkualitas antar karyawan dapat terjadi apabila diantara karyawan terdapat komunikasi yang efektif (Hermawan, 2008). Jika karyawan sudah memiliki komunikasi interpesonal yang baik dan efektif maka tentu akan tercapai kesamaan makna yang diharapkan akan terwujudnya tindakan kolektif yang sama, sesuai, dan bersifat asosiatif.

Berdasarkan hasil observasi dan wawancara, didapatkan bahwa memang karyawan fokus sibuk untuk mencapai target pekerjaanya saja, karyawan mengungkapkan bahwa memang masih minimnya perilaku altruisme di lingkungan kerja mereka, hal itu disebabkan oleh beberapa hal seperti karyawan hanya fokus untuk menyelesaikan tugas-tugas individunya yang menyebabkan kurangnya keterbukaan dalam komunikasi, hal ini pun berdampak pada minimnya terjadi perilaku OCB diantara karyawan. Ketika pekerjaan mereka terasa sulit rekan kerjanya hanya memberi bantuan dengan saran saja tanpa ada tindakan nyata untuk menolong dengan berbagai alasan seperti kurang mengerti, ada urusan lain, takut salah, dan tidak merasa berwenang untuk mengerjakannya.

\section{Tinjauan Literatur}

\section{A. Organizational Citizenship Behavior}

Kartz (dalam Sumiyarsih dkk, 2012) menekankan bahwa Organizational Citizenship Behavior adalah perilaku-perilaku kooperatif dan saling membantu yang berada di luar persyaratan formal yang sangat penting bagi berfungsinya suatu organisasi. Menurut Organ (dalam Kusumajati,2014) organizational citizenship behavior (OCB) adalah kebebasan perilaku individu, yang secara tidak langsung atau eksplisit diakui oleh sistem reward, dan memberi kontribusipada keefektifan dan keefisienan fungsi organisasi. OCB juga sebagai perilaku dan sikap 
yangmenguntungkan organisasi yang tidak bisa ditumbuhkan dengan basis kewajiban peran formal maupundengan bentuk kontrak atau rekompensasi.

Greenberg \& Baron (dalam Sumiyarsih dkk,2012) mendefinisikan OCB sebagai perilaku yang bersifat informal,melebihi harapan normal organisasi dan semuanya itu pada akhirnya dapat menjadikan kesejahteraan organisasi.

\section{Dimensi-dimensi OCB}

Menurut Organ (dalam Dewi \& Fransistya, 2017) terdapat lima dimensi pada OCB yakni : a. Altruisme, merupakan perilaku karyawan dalam menolong rekan kerjanya yang
mengalami kesulitan dalam situasi yang sedang dihadapi baik mengenai tugas dalam organisasi maupun masalah pribadi.
b. Courtesy, merupakan perilaku menjaga hubungan baik dengan rekan kerja agar terhindar dari masalah interpersonal.
c. Sportmanship, merupakan perilaku yang memberikan toleransi terhadap keadaan yang kurang ideal dalam organisasi tanpa mengajukan keberatan-keberatan.
d. Conscientiousness, merupakan perilaku yang ditunjukan dengan berusaha melebihi yang diharapkan perusahaan.
e. Civic virtue,merupakan perilaku yang mengindikasikan tanggung jawab pada kehidupan organisasi.

\section{B. Komunikasi Interpersonal}

Menurut De Vito (dalam Liliweri, 1997) komunikasi interpersonal atau komunikasi antarpribadi merupakan pengiriman pesan dari seseorang dan diterima oleh orang lain dengan efek dan umpan balik yang langsung. Sementara itu menurut Effendy (dalam Liliweri, 1997) pada hakikatnya komunikasi interpersonal atau komunikasi antarpribadi adalah komunikasi antara seseorang komunikator dengan komunikan. Jenis komunikasi tersebut dianggap paling efektif untuk mengubah sikap, pendapat, atau perilaku manusia berhubung prosesnya yang dialogis. Luthans (dalam Oktavia, 2016) juga mengungkapkan bahwa komunikasi interpersonal adalah metode dasar yang mempengaruhi perubahan dasar perilaku.

\section{Aspek-aspek Komunikasi Interpersonal}

Menurut De Vito (dalam Walgito, 2006) terdapat lima aspek dalam komunikasi interpersonal yang efektif :

a. Openness, keterbukaan dalam komunikasi interpersonal, diantaranya mengandung keinginan untuk mengungkapkan diri (self-disclose) saat memberikan informasi mengenai diri sendiri yang umumnya disembunyikan. Pengungkapan diri yang bilateral dan pertukaran informasi yang timbal balik.

b. Empathy, merasakan seperti yang dirasakan oleh orang lain atau mengalami seperti yang dialami oleh orang lain tanpa menghilangkan identitas diri.

c. Supportiveness, kalau dalam komunikasi seseorang mengevaluasi positif terhadap orang lain, maka akan memberikan dukungan kepadanya. Sebaliknya, kalau evaluasinya negatif, orang tidak akan memberikan dukungan kepadanya.

d. Positiveness, Perasaan seseorang (positif atau negatif) akan jelas terlihat selama pembicaraan dan akan mempengaruhi kepuasan atau ketidakpuasan interaksi, komunikasi interpersonal memerlukan adanya positive thinking, terutama kepada orang yang diajak berkomunikasi di samping sikap positif pada diri sendiri dan situasi komunikasi. 
e. Equality,pengakuan bahwa kedua belah pihak memiliki kepentingan dan pengakuan bahwa kedua belah pihak sama-sama bernilai dan saling membutuhkan.

\section{Metodologi}

Metode pada penelitian ini menggunakan metode kuantitatif. Adapun variabel yang diukur pada penelitian ini adalah sebagai berikut :

Variabel Dependen : Organizational Citizenship Behavior

Variabel Independen : Komunikasi Interpersonal

Populasi dalam penelitian ini adalah seluruh karyawan Departemen Sumber Daya Manusia PT. Semen Padang sebanyak 75 orang. Adapun teknik sampling yang digunakan dalam penelitian ini adalah sampling jenuh, yaitu teknik pengambilan sampel bila semua anggota populasi digunakan sebagai sampel (Sugiyono, 2013). Pada penelitian ini yang menjadi sampel penelitian adalah 75 orang karyawan dari departemen sumber daya manusia PT. Semen Padang.

Metode pengumpulan data yang digunakan dalam penelitian ini adalah metode skala. Menurut Azwar (2014) alasan menggunakan metode skala yaitu karena subjek adalah orang yang paling tahu tentang dirinya sendiri. Skala yang digunakan pada penelitian ini adalah skala komunikasi interpersonal dan organizational citzenship behavior dengan model likert yaitu suatu metode pernyataan sikap yang menggunakan respon subjek sebagai penentu nilai skalanya yang telah dimodifikasi menjadi empat alternatif jawaban dan aitem-aitem dalam skala ini dikelompokkan dalam aitem favorable dan unfavorable. Bentuk skala yang digunakan untuk mengukur komunikasi interpersonal dan skala organizational citizenship behavior menggunakan empat alternatif jawaban, yaitu SS (Sangat Setuju), S (Setuju), TS (Tidak Setuju), dan STS (Sangat Tidak Setuju).

Kriteria pemberian skor untuk skala komunikasi interpersonal dan organizational citizenship behavior dengan ketentuan sebagai berikut :

Tabel 1. Kriteria Pemberian Skor

\begin{tabular}{|l|c|c|}
\hline \multirow{2}{*}{\multicolumn{1}{|c|}{ Jawaban }} & \multicolumn{2}{c|}{ Skor } \\
\cline { 2 - 3 } & Favorable & Unfavorable \\
\hline Sangat Setuju (SS) & 4 & 1 \\
\hline Setuju (S) & 3 & 2 \\
\hline Tidak Setuju (TS) & 2 & 3 \\
\hline Sangat Tidak Setuju (STS) & 1 & 4 \\
\hline
\end{tabular}

Skala dalam penelitian ini dianalisis dengan menggunakan teknik korelasi Product Moment Pearson, yang merupakan salah satu teknik mencari derajat keeratan atau keterikatan antar variabel independen dengan variabel dependen (Azwar, 2012). Skala penelitian ini melewati berbagai tahap analisis, dengan menggunakan bantuan program SPSS versi 22.0 for windows. Tahap-tahap analisis yang dilakukan yaitu :

1. Uji Normalitas

Uji normalitas bertujuan untuk mengetahui apakan data dalam penelitian ini sudah terdistribusi sesuai dengan prinsip-prinsip distribusi normal agar dapat digeneralisasikan terhadap populasi. Uji normalitas dilakukan untuk mengetahui apakah sebaran suatu data 
tersebut normal atau tidak. Uji normalitas sebaran pada penelitian ini dilakukan untuk membuktikan bahwa data semua variabel yang berupa skor-skor yang diperoleh dari hasil penelitian tersebar sesuai dengan kaidah normal. Uji normalitas dalam penelitian ini menggunakan one sample test dari Kolmogorov Smirnov dengan bantuan program SPSS versi 22.0 for windows (Azwar, 2012).

2. Uji Linieritas

Uji linearitas bertujuan untuk membuktikan apakah variabel bebas mempunyai hubungan yang linear dengan variabel terikat. Model statistik yang digunakan untuk melihat linearitas kedua variabel tersebut menggunakan test for linearity dengan bantuan program SPSS versi 22.0 for windows (Azwar, 2012).

\section{Uji Hipotesis}

Uji hipotesis bertujuan untuk mengetahui apakah kesimpulan pada sampel dapat berlaku untuk populasi atau dapat digeneralisasi (Priyatno, 2013). Uji hipotesis dalam penelitian ini menggunakan teknik korelasi Product Moment Person untuk mencari hubungan variabel dependen dengan variabel independen. Uji hipotesis korelasi yang digunakan dalam penelitian ini adalah jika $\mathrm{p}<0,05$, maka dikatakan bahwa kedua variabel penelitian mempunyai kontribusi hubungan yang signifikan. Data penelitian dianalisis dengan menggunakan bantuan komputer Statistical Programme for Social Science (SPSS) versi 22.0 for Windows.

\section{Hasil dan Diskusi}

\section{A. Hasil Uji Hipotesis}

Uji hipotesis bertujuan untuk mengetahui apakah kesimpulan pada sampel dapat berlaku untuk populasi atau dapat digeneralisasi (Priyatno,2013). Uji hipotesis dalam penelitian ini menggunakanteknik korelasi product moment dari Pearson dengan menggunakan bantuan program komputer. Berdasarkan hasil pengolahan data mengenai hubungan antara komunikasi interpersonal dan OCB pada karyawan departemen sumber daya manusia PT.Semen Padang sebanyak 75 orang, maka diperoleh hasil sebagai berikut:

Tabel 2. Uji Korelasi

\begin{tabular}{|c|c|c|}
\hline $\mathbf{N}$ & $\mathbf{P}$ & Nilai korelasi (r) \\
\hline 70 & 0,000 & 0,455 \\
\hline
\end{tabular}

Berdasarkan uraian tabel di atas, maka diperoleh koefisien korelasi antara variabel komunikasi interpersonal dan variabel OCB sebesar $r=0,455$ dengan taraf signifikansi $\mathrm{p}=0,000$, maka dapat disimpulkan bahwa ada hubungan antara komunikasi interpersonal dan OCB dengan arah hubungan positif. Hal ini berarti apabila komunikasi interpersonal efektif, maka akan muncul perilaku OCB yang tinggi, begitu juga sebaliknya apabila komunikasi interpersonal tidak efektif atau buruk maka perilaku OCB yang ditimbulkan akan rendah.

Berikut tabel deskriptif statistik dari variabel komunikasi interpersonal dan OCB berdasarkan mean empirik sebagai berikut :

Tabel 3. Descriptive Statistic

\begin{tabular}{|c|c|c|c|c|c|}
\hline Variabel & $\mathbf{N}$ & Mean & Std.Deviation & Minimum & Maximum \\
\hline Komunikasi & 70 & 99,20 & 3,110 & 93 & 107 \\
\hline
\end{tabular}




\begin{tabular}{|c|c|c|c|c|c|}
\hline Interpersonal & & & & & \\
\hline OCB & 70 & 113,59 & 3,653 & 106 & 122 \\
\hline
\end{tabular}

Analisis data yang dilakukan terhadap penilaian skor sampel penelitian, baik pada komunikasi interpersonal maupun OCB yang berjumlah 75 orang. Analisis data dilakukan untuk mengetahui perbedaan kategori skor sampel komunikasi interpersonal maupun OCB. Berdasarkan nilai mean empiric maka skor sampel dapat dikategorikan kedalam tiga kategori yaitu tinggi, sedang dan rendah (Azwar, 2012).

Tabel4. Norma Kategorisasi

\begin{tabular}{|c|c|}
\hline Norma & Kategorisasi \\
\hline $\mathrm{X}<(\mu-1,0 \sigma)$ & Rendah \\
\hline$(\mu-1,0 \sigma) \leq \mathrm{X}<(\mu+1,0 \sigma)$ & Sedang \\
\hline$(\mu+1,0 \sigma) \geq \mathrm{X}$ & Tinggi \\
\hline
\end{tabular}

Keterangan:

$$
\begin{aligned}
\mu & =\text { mean } \\
\sigma & =\text { standar deviasi } \\
\mathrm{X} & =\text { Skor mentah sampel }
\end{aligned}
$$

Tabel 5. Pengelompokkan Kategorisasi Subjek

\begin{tabular}{|c|c|c|c|c|}
\hline Variabel & Skor & Jumlah & Persentase & Kategori \\
\hline Komunikasi & $<96$ & 8 & $11 \%$ & Rendah \\
\cline { 2 - 5 } Interpersonal & $96-102$ & 53 & $76 \%$ & Sedang \\
\cline { 2 - 5 } & $\geq 102$ & 9 & $13 \%$ & Tinggi \\
\hline \multirow{3}{*}{ OCB } & $<109$ & 5 & $7 \%$ & Rendah \\
\cline { 2 - 5 } & $109-117$ & 52 & $74 \%$ & Sedang \\
\cline { 2 - 5 } & $\geq 117$ & 13 & $19 \%$ & Tinggi \\
\hline
\end{tabular}

Berdasarkan tabel di atas, maka dapat diperoleh gambaran bahwa sebesar 11\% komunikasi interpersonal dikategorikan rendah, sebesar $76 \%$ komunikasi interpersonal dikategori sedang dan sebesar $13 \%$ komunikasi interpersonal dikategori tinggi sedangkan untuk variabel OCB diperoleh gambaran bahwa sebesar 7\% OCB dikategori rendah, sebesar 74\% OCB dikategori sedang dan sebesar 19\% OCB dikategori tinggi.

\section{B. DISKUSI}

Penelitian ini bertujuan untuk mengetahui hubungan antara komunikasi interpersonal dengan organizational citizenship behavior pada karyawan departemen sumber daya manusia PT.Semen Padang. Berdasarkan uji hipotesis yang dilakukan menunjukan bahwa terdapat hubungan yang signifikan antara komunikasi interpersonal dengan organizational citizenship behavior pada karyawan departemen sumber daya manusia PT.Semen Padang yang ditunjukkan oleh angka koefisien korelasir $_{x y}=0,455$ dengan tingkat signifikansi korelasi $\mathrm{p}=0,000$. Nilai yang positif pada koefisien korelasimenunjukkan hubungan positif antara komunikasi interpersonal dengan organizational citizenship behavior pada karyawan departemen sumber daya manusia PT.Semen Padang, artinyabahwa semakin tinggi tingkat komunikasi interpesonal maka semakin tinggi pula perilaku organizational citizenship behavior yang ditampilkan karyawan, dan sebaliknya semakin rendah tingkat 
komunikasi interpersonal maka semakin rendah tingkat perilaku organizational citizenship behavior yang ditampilkan oleh karyawan.

Banyak faktor-faktor yang mempengaruhi seorang karyawan sehingga karyawan bersedia menampilkan perilaku seperti OCB untuk menjadi good citizen. George dan Brief (dalam Novianto, 2009) berpendapat kualitas interaksi antara sesama karyawan dan iklim kelompok kerja yang positif akan mempengaruhi suasana hati seseorang dalam mengambil keputusan untuk melakukan tindakan membantu orang lain. Interaksi yang baik diantara anggota organisasi akan dapat membentuk pola komunikasi yang asosiatif . Interaksi yang berkualitas antar karyawan dapat terjadi apabila diantara karyawan terdapat komunikasi interpersonal yang efektif (Hermawan, 2008).

Shweta dan Srirang (2010) juga mengatakan terdapat beberapa faktor yang mempengaruhi munculnya perilaku OCB dalam organisasi yakni, disposisi individu dan motif individu, kohesivitas kelompok, kepemimpinan, sikap anggota (komitmen organisasi) dan komunikasi interpersonal.Jika karyawan sudah memiliki komunikasi interpesonal yang baik dan efektif maka tentu akan tercapai kesamaan makna yang diharapkan akan terwujudnya tindakan kolektif yang sama, sesuai, dan bersifat asosiatif. Komunikasi interpersonal yang efektif diharapkan membantu karyawan dalam mewujudkan perilaku kolektif baik yang bersifat in role ataupun extra role sebab didalam organisasi tentu tidak akan lepas dari bagaimana sumber daya manusia yang bekerja didalamnya.

Dilihat dari penilain deskriptif terhadap 70 orang karyawan PT Semen Padang pada bagian departemen sumber daya manusia, dapat diketahui bahwa sebesar $11 \%$ komunikasi interpersonal dikategorikan rendah, sebesar $76 \%$ komunikasi interpersonal dikategori sedang dan sebesar $13 \%$ komunikasi interpersonal dikategori tinggi sedangkan untuk variabel OCB diperoleh gambaran bahwa sebesar 7\% OCB dikategori rendah, sebesar 74\% OCB dikategori sedang dan sebesar 19\% OCB dikategori tinggi. Adapun besar sumbangan efektif dari komunikasi interpersonal terhadap OCB adalah sebesar $21 \%$ sedangkan $79 \%$ lagi dipengaruhi oleh faktor lain seperti disposisi individu dan motif individu, kohesivitas kelompok, keadilan organisasi, kualitas interaksi atasan dan bawahan dan sikap anggota (Shweta dan Srirang, 2010).

\section{Kesimpulan}

Berdasarkan hasil analisis dan pembahasan yang diuraikan sebelumnya, maka ditarik kesimpulan yang sekaligus merupakan jawaban dari tujuan penelitian ini yaitu:

Terdapat hubungan positif yang signifikan antara komunikasi interpersonal dengan organizational citizenship behavior pada karyawan departemen sumber daya manusia PT. Semen Padang. Tingkat komunikasi interpersonal dan tingkat organizational citizenship behavior dalam penelitian ini tergolong sedang. Sumbangan komunikasi interpersonal terhadap organizational citizenship behavior pada karyawan Departemen Sumber Daya Manusia PT. Semen Padang sebesar $21 \%$.

\section{Referensi}

Azwar,S.2012.PenyusunanSkalaPsikologi.Yogyakarta:PustakaBelajar.

.2014. Metodologi Penelitian. Yogyakarta: Pustaka Belajar.

Amanda, Agustiani Rifania. 2014. Pengaruh Employee Communication Terhadap Organizational Citizenship Behavior yang Dimediasi Oleh Employee Engagement pada Karyawan di Beberapa Fakultas Universitas Tri Sakti Jakarta. Jurnal Manajemen dan Pemasaran Jasa. Volume 7, No.1. 
Dewi, Rooswita S. dan Prima Yudha Fransistya. 2017. Organizational Citizenship Behavior Pada Pengurus Kelompok Studi Islam Asy Syifa Fakultas Kedokteran Universitas Lambung Mangkurat. Jurnal Psikologi. Volume 4, No.2.

Hermawan, Wawan. 2008. Pengantar Sosiologi. Jakarta : Penerbit Kencana

Kusumajati, Dian Anggraini. 2014. Organizational Citizenship Behavior Karyawan Pada Perusahaan. Jurnal Humaniora. Volume 5, No.1.

Liliweri, Ali. 1997. Komunikasi Antar Pribadi. Bandung. Citra Aditya Bakti.

Novianto, Indri. 2009. Hubungan Komunikasi Interpersonal yang Efektif dan Organizational Citizenship Behavior Pada Karyawan Bagian Produksi Fitting PT. Wavin Duta Jaya. Skripsi. Fakultas Psikologi Universitas Sanata Dharma Yogyakarta.

Priyatno, Dwi. 2013. Mandiri Belajar SPSS Untuk Analisis Data. Jakarta:Mediakom.

Setyawanti, Erna. 2012. Pengaruh Tingkat Kecerdasan Emosi dan Sikap Budaya Organisasi TerhadapOrganizational Citizenship Behavior Pegawai PT PLN (PERSERO)Area Pelayanan dan Jaringan (APJ) Purwokerto. Jurnal Probisnis. Volume 5, No.2.

Shweta, Jha dan Srirang Jha. 2010. Determinant of Organizational Citizenship Behavior: A Review of Literature. Journal of Management \& Public Policy. Volume 1, No.2.

Sugiyono.2013. Metode Penelitian Kuantitatif,Kualitatif dan R\&D. Bandung.Alfabeta

Sumiyarsih, Wiwik, Endah M., Jati A. 2012. Hubungan Antara Kecerdasan Emosional dengan Organizational Citizenship Behavior Pada Karyawan CV Aneka Ilmu Semarang. Jurnal Psikologi. Volume 11,No.1.

Walgito, Bimo. 2006. Psikologi Kelompok. Yogyakarta. Penerbit Andi. 